\title{
"Sometimes Climate Adaptation is Politically Correct": A Case Study of Planners and Politicians Negotiating Climate Adaptation in Waterfront Spatial Planning
}

Sofie Storbjörk and Mattias Hjerpe

\author{
Linköping University Post Print
}

\section{Tweet}

N.B.: When citing this work, cite the original article.

This is an electronic version of an article published in:

Sofie Storbjörk and Mattias Hjerpe, "Sometimes Climate Adaptation is Politically Correct": A Case Study of Planners and Politicians Negotiating Climate Adaptation in Waterfront Spatial Planning, 2014, European Planning Studies, (22), 11, 2268-2286.

European Planning Studies is available online at informaworldTM:

http://dx.doi.org/10.1080/09654313.2013.830697

Copyright: Taylor \& Francis (Routledge): SSH Titles http://www.routledge.com/

Postprint available at: Linköping University Electronic Press http://urn.kb.se/resolve?urn=urn:nbn:se:liu:diva-96664 


\title{
"Sometimes Climate Adaptation is Politically Correct": A Case Study of Planners and Politicians Negotiating Climate Adaptation in Waterfront Spatial Planning
}

Sofie Storbjörk (corresponding author), Department of Water and Environmental Studies (DWES) and Centre for Climate Science and Policy Research (CSPR), Linköping University, 58183 LINKÖPING, Sweden, Phone: +46 13 282952, e-mail: sofie.storbjork@liu.se

Mattias Hjerpe, Department of Water and Environmental Studies (DWES) and Centre for Climate Science and Policy Research (CSPR), Linköping University, 58183 LINKÖPING, Sweden, Phone: +46 11 363438, e-mail: mattias.hjerpe@liu.se

\begin{abstract}
Today, spatial planning is expected to deliver climate adaptation and to manage, merge and balance various societal interests and priorities. To what extent proactive shaping of change is enabled by spatial planning practice is less explored. This paper illustrates how the ideals and ambitions of climate adaptation are manifested in waterfront spatial planning via a case study of Norrköping, Sweden. Based on interviews with spatial planners and politicians responsible for strategic urban development planning, our study identifies a divergence in ambitions, approaches and positions. In local development plans, the position taken has less to do with climate risk severity than with an area's perceived political and economic attractiveness. When perceived attractiveness is low, precautionary climate adaptation serves as a pretext not to develop, whereas high perceived attractiveness leads to negotiated pragmatism allowing continued waterfront exploitation. We also identify a fragmentation in spatial planning, with weak interplay between municipal comprehensive planning and local development plans, resulting in ad hoc, case-by-case planning. Furthermore, different planning actors are organizationally compartmentalized, creating unfortunate intra-sectoral silos. We conclude that the integrative, proactive and reflexive potentials of spatial planning to deliver climate adaptation have yet to be realized.
\end{abstract}

Keywords: climate adaptation, policy integration, spatial planning, waterfront planning, caseby-case planning, fragmentation 
Spatial planning is now recognized as an important policy field for managing climate change mitigation and adaptation (Biesbroek et al., 2009; Campbell, 2006; Davoudi et al., 2009; Wilson, 2006; Wilson \& Piper, 2010). Wilson and Piper (2010, p. 10) define spatial planning as "the ability to plan, in a democratically accountable way, the activities of ... sectors (such as housing, energy, economic development, transport and water ... that have spatial or landuse consequences in their wider social and environmental context". In this view, spatial planning transcends the mere technical and legal regulation of land use change (Albrechts, 2010; Bramley \& Kirk, 2005; Tewdwr-Jones et al., 2010; Vigar, 2009). Instead, planning is assigned a coordinating role of integrating and balancing current and future societal goals, considerations and knowledge claims. Here planning is regarded as having both strategic and reflexive potential, implying an ability to concretize choices and alternative development paths (Albrechts, 2010; Healey, 2009; Hillier \& Healey, 2010).

Climate adaptation scholars and policy makers have gradually placed new demands on spatial planning, requiring it to deliver climate adaptation and ensure adequate consideration of climate change (Wilson \& Piper, 2010). Spatial planning is a means to improve policy coordination and integration between competing interests, across sectors and between governance levels to achieve locally adequate spatial solutions with long-term societal benefits (Hurlimann \& March, 2012; Stead \& Meijers, 2009). Climate change becomes part of spatial planning through the mechanisms of policy integration and mainstreaming (Glaas, 2013; Smit \& Wandel, 2006; Urwin \& Jordan, 2008), which incorporate climate change considerations into the routines and operations of the spatial planning system (Uittenbroek et al., 2012). Climate adaptation scholars and policy makers clearly have great hopes of the integrative potential of spatial planning to manage, merge and balance the consequences of climate change with other societal interests. However, both the local climate governance and climate adaptation literatures have documented an implementation gap in planning for climate change, in which the integration of climate change considerations tends either to remain rhetorical or to result in limited application (Blanco \& Alberti, 2009; Bulkeley, 2006; Bulkeley \& Betsill, 2005; Glaas et al., 2010; Granberg \& Elander, 2007; Measham et al., 2011; Romero-Lankao, 2012; Runhaar et al., 2011; Storbjörk, 2007; Uggla, 2009). Hurlimann and March (2012) note that key challenges arise due to the political nature of spatial planning, long recognized in the planning research community (Forester, 1989; Friedmann, 1987,), and suggest transforming planning systems from passive and regulatory to proactive, shaping change.

In spatial planning, climate adaptation has often been associated with protecting urban settlements and infrastructure from increasing exposure to flooding, erosion and landslides, as aggravated by climate change (Bulkeley, 2006). Accordingly, spatial planning faces a particular challenge in managing waterfront settlements in coastal zones or near inland lakes and watercourses in a changing climate, as this involves "safety versus scenery" conflicts. Previous studies clearly state that current trends in waterfront spatial planning are problematic for local climate adaptation due to these conflicting intentions and priorities (Bulkeley, 2006; Romero-Lankao, 2012; Storbjörk, 2007; Uggla, 2009; Wilby \& Keenan, 2012). Yet still, we 
lack knowledge of the intricacies involved in the practice of waterfront spatial planning. This "black box" needs to be opened and targeted for further research.

The aim of this paper is to examine how the ideals and ambitions of climate adaptation are manifested in waterfront spatial planning practices, empirically exemplified by an explorative case study in the municipality of Norrköping, Sweden. The study is based on interviews with spatial planners and politicians responsible for both municipal comprehensive planning and local development plans, and analysis of key planning documents. Specifically, the following questions are targeted:

1. What are the general ambitions, approaches and positions of current waterfront spatial planning?

2. What are the concrete outcomes of climate adaptation in waterfront local development planning?

3. To what extent is integrative and proactive potential enabled in the current orientation and manifestation of spatial planning? What challenges are encountered?

After this introductory section follows an account of methodological considerations. Our analytical framework, incorporating perspectives on the ideals and practice of spatial planning, is presented in section three, followed by an introduction to the Swedish policy context of climate adaptation. Section five presents our qualitative analysis targeting the current ambitions, approaches and positions of waterfront planning, the conflicting principles, ideals and agendas of local development planning and, finally, the current fragmentation of the planning sector. In the sixth and final section, the main conclusions are drawn.

\section{Methodological Considerations}

Norrköping is located in the north-eastern part of the East Sweden Region on the Baltic coast, about 170 kilometres south of Stockholm. The municipality is $1491 \mathrm{~km}^{2}$ in area and its population totalled 132,000 as of December 2012 (Norrköping, 2012). Historically, Norrköping has been an industrial and trading town and an important regional communications node for shipping, train, highway, and air traffic. Its current slogan, "Let's create Norrköping", depicts Norrköping as "in constant transformation" with "creative, knowledge-driven enterprise" (Norrköping, 2012). We selected Norrköping because previous work in the region (Johansson et al., 2009) gave us knowledge of ongoing activities with a bearing on our research questions. Norrköping conducts an active strategic spatial planning for new housing and planning for waterfront areas; in addition, it has recently prepared an appendix on local risks, including climate change, to supplement its municipal comprehensive plan.

Empirically, we started in 2010 by conducting two qualitative interviews with leading municipal politicians, in government and opposition, responsible for urban planning and building in the city council. Second, based on examples mentioned in these interviews, in 
2011, we analyzed potential waterfront development plans in Norrköping. Third, in 2012, we conducted two focus-group interviews with planning officials from the city planning office (henceforth, "planners") and politicians from the town planning committee (henceforth, "politicians"). The first focus group consisted of three planners involved in municipal comprehensive planning and/or local development planning with a bearing on waterfront housing and climate risk. The second group consisted of five politicians from the town planning committee, representing different political parties. The new chair of the town planning committee was interviewed separately, since there had been a recent change in committee leadership. The focus group interviews considered how climate change was approached in both strategic spatial planning and concrete development plans. In the focus groups, interviewees reflected extensively on how spatial planning was organized (e.g. the relationship between comprehensive and development planning) and on the role of agency. Several examples of development plans featured in the interviews, which also examined the two ongoing plans for Kanaljorden and Lindö. These plans were selected from the first interviews and the analysis of waterfront development plans. We wanted two fairly recent plans for different geographical locations. Lindö is a suburb of Norrköping with a view of the Baltic Sea, whereas Kanaljorden is a rural area located inland near the Göta Canal, about 20 kilometres from the city centre. During the interviews, it became clear that the approaches to climate risks differed between the two plans, which enabled interesting comparisons.

[Insert Table 1 here]

Our eleven interviewees with different roles and positions in local spatial planning allow us a broad and in-depth qualitative analysis of important voices - perspectives, viewpoints and experiences - regarding the theory and practice of climate adaptation in waterfront spatial planning in Norrköping. The individual interviews lasted approximately two hours and the focus group interviews approximately three hours each; all interviews were recorded and transcribed. The analysis was stepwise. First, we concentrated the meanings in the transcribed text, focusing on the specific contents and various recurring analytical themes featuring in the responses. Second, for this paper, we highlighted themes with a particular bearing on waterfront planning and the three research questions. When presenting the empirical results, we emphasize statements and reflections from key actors; in this, we have chosen to present a combination of individual viewpoints and more general patterns from the interview and focus group material. Is however important to note that the analysis presented in the paper represents a singular explorative case study of waterfront planning, offering tentative conclusions for how the ideals of climate adaptation are played out in practical waterfront planning. Here we follow Flyvbjerg's (2007) understanding that single-case studies may serve as a sound basis for research if the case in question, like the one in Norrköping, is rich and illustrative enough.

Analytical Framework: The Ideals and Practice of Spatial Planning

Recent planning theory has suggested a shift from traditional land use planning, supporting the technical and legal regulation of land, to spatial planning based on co-aligning and 
integrating strategies and policies. This integrative element of spatial planning endeavours to avoid conflicting policies while broadening existing policy frames, linking actors and closing implementation deficits (Inch, 2012; Tewdwr-Jones et al., 2010; Vigar, 2009). In the UK context, it is claimed that "spatial planning goes beyond traditional land use planning by integrating policies for the development and use of land with other policies and programs which influence the nature of places and how they function" (Clifford, 2012, p. 2. See also Albrechts, 2010; Bramley \& Kirk, 2005; Tewdwr-Jones et al., 2010; Vigar, 2009). Another element of spatial planning involves proactively and strategically managing and influencing change (Tewdwr-Jones et al., 2010, p. 240). Healey (2009) has stated that all planning work is strategic in that a wide range of considerations are integrated, but that spatial strategy making is more fundamentally transformative. This means that planning is "geared to efforts to change direction, to open up new possibilities and potentials, and to move away from previous positions" (Healey, 2009, p. 440). Here proactive spatial planning thus entails both a strategic and a reflexive potential, implying to concretize choices and alternative development paths (Albrechts, 2010; Hillier \& Healey, 2010)

Among climate adaptation scholars, the most examined element of spatial planning is its integrative potential. This is illustrated by Hurlimann and March (2012, p. 480), who outline the roles and functions of current spatial planning expected to facilitate climate adaptation:

1. Planning has the ability to act on and coordinate matters of collective concern or public good

2. Planning can manage and facilitate the consideration of competing interests

3. Planning is a way of thinking and action across various spatial, temporal and governance scales while understanding and acting on local circumstances and particularities

4. Planning can reduce or modify uncertainty and provide new mechanisms to deal with changing circumstances

5. Planning has the capacity to be a repository for spatial knowledge sets

6. Planning is oriented to the future, and has the potential to coordinate the activities of a range of actors to achieve long-term benefits

All six capacities involve, in one way or another, integrating various perspectives, claims and knowledge, clearly assuming that planning can manage, merge and balance current and future societal goals, intentions and considerations. However, the proactive and reflexive potential of spatial planning is less explored.

Alongside this discussion of the broadened roles, functions and approaches of spatial planning, a substantial strand of research problematizes the extent to which one can identify strategic spatial planning in practice. Olesen and Richardson (2012, p. 1690) speak of a "potential watershed between a renewed interest in and crisis of 'strategic spatial planning". Healey (2009) states that many strategies "do little 'strategic work' in the sense of shaping 
future development trajectories" (p. 439). Others have demonstrated that spatial planning is in practice based on various aspirations and contradictory narratives regarding land use change (Clifford, 2012; Inch, 2012). There is also evidence of planners being stuck in the working practices of old land use planning, uncommitted to the proposed change, suggesting that integration in practice depends on local circumstances, traditions and path dependencies (Clifford, 2012; Tewdwr-Jones et al., 2010; Vigar, 2009).

Furthermore, researchers have documented spatial planning's difficulties fulfilling its integrative and proactive potential: since spatial decisions are reached in a piecemeal manner, the end results are often partial solutions to challenges rather than grand transformations (Newman, 2008). Mickwitz et al. (2009, p. 60) claim that the capacities of spatial planning are shrinking due to "the rigidity of administrative and political borders, the stability of departmentalism and the strength of sectional interests and preferences for small-scale solutions". Such fragmentation in the form of "silo mentalities" and cross-sectoral mismatches in integrating critical concerns has been problematized in both planning studies (Blanco \& Alberti, 2009; Healey, 2007; Isaksson \& Storbjörk, 2012; Nilsson, 2007; Vigar, 2009) and adaptation studies (Glaas et al., 2010; Lidskog \& Uggla, 2009; Mickwitz et al., 2009; Næss et al., 2005; Romero-Lankao, 2012; Storbjörk, 2010; Wilby \& Keenan, 2012; Wilson, 2006). Fragmentation is also evident in the interplay between planning instruments, such as municipal comprehensive and local development plans (Hilding-Rydevik \& Åkerskog, 2011; Measham et al., 2011; Vigar, 2009). In practice, comprehensive plans aiming at flexibility have impeded the implementation and leverage of strategic planning goals and also supported a tendency for case-by-case planning. Hrelja (2011, p. 521) has called for more problematization of the unreflected "tyranny of small decisions", creating long-lasting material structures for urban development. Such intra-sectoral components of spatial planning are critical when assessing the extent to which integrating efforts are realized.

\section{National Policy Context}

The Swedish climate change strategy has developed gradually since the late 1980s. In 2002, the Swedish parliament decided on a combination of "carrots, sticks and sermons" to serve as the national strategy for reducing emissions (Lundqvist \& Biel, 2007, p. 17ff). Since 2004, climate adaptation has gradually been recognized as a policy issue requiring national, regional and local management in Sweden. No coherent national adaptation strategy exists yet, and climate adaptation has been characterized by a combination of voluntary efforts, networkcoordinating initiatives, governmental commissions, knowledge generation and legislative demands on municipalities (Keskitalo et al., 2012; Storbjörk, 2012; Uggla, 2009). Rydell et al. (2010) have documented 74 activities relating to climate adaptation undertaken by various national authorities, mainly in urban planning, technical infrastructure and agriculture. The main adaptation work, however, is expected to take place in the 290 municipalities, where policy documents highlight spatial planning as a key instrument for driving change.

Municipalities in Sweden have extensive responsibilities for spatial planning and building, drainage and water supply, emergency planning and rescue services. Compared with other EU 
countries, Sweden lacks strong regional planning to coordinate state and municipal land use planning (EC, 2000). Instead, Swedish municipalities' autonomy and 'local planning monopoly" gives them the exclusive right to develop and adopt local land use plans (Lundqvist \& Borgstede, 2008). Local spatial planning is structured around municipal comprehensive plans and local development plans, the former specifying long-term land use goals. Since comprehensive plans are not binding, local development planning is particularly influential in guiding change (Boverket, 2010). Since January 2008, municipalities have had to consider the consequences of climate change in spatial planning, according to the Planning and Building Act (Boverket, 2009, 2010). Swedish municipalities clearly need to consider climate change and its consequences when assessing the suitability of locations in comprehensive and development plans and when granting building and construction permits. Early studies demonstrated that Swedish municipalities had difficulties addressing climate risks and adaptation in policy and strategy making (Glaas et al., 2010; Granberg \& Elander, 2007; Storbjörk, 2007; Uggla, 2009). Only a few years later, a self-evaluation survey suggested that $90 \%$ of the 200 responding municipalities claimed to be addressing adaptation in spatial planning in some way (SKL, 2009). The survey, however, did not indicate how these municipalities were concretely addressing climate adaptation in spatial planning practices, though follow-up studies have identified a broad range of interpretations and practical outcomes (Uggla \& Storbjörk, 2012). This national policy context is the starting point of this study.

Planning amidst Various Planning Goals, Positions and Practices

First we present the ambitions, approaches and positions of waterfront spatial planning in Norrköping. Second, we identify the conflicting principles, ideals and agendas at play in the two current examples of Kanaljorden and Lindö. Finally, we problematize the current fragmentation of spatial planning.

\section{Waterfront Planning: Ambitions, Approaches and Positions}

The interviewees note the political ambition of urban expansion in Norrköping, where spatial planning has come to entail decisions about where, what and how to build (Interviewees 111). The planners discuss the role of planning, largely in line with the planning ideal expressed in contemporary planning research, as facilitating compromises between preservation and exploitation and promoting sustainable urban qualities, thus acknowledging planning as being inherently political (Interviewees 4-6; Tewdwr-Jones et al., 2010; Vigar, 2009). In practice this means managing the politics of planning, planners being torn between merging and mediating the goals considered in spatial planning and current local political ambitions (Interviewees 4, 5). Planners emphasize that planning means taking long-term responsibility for city structures, land use and development, as also emphasized by politicians: 
We have both an auditing function, to assess ongoing activities and ensure that the right decisions are made, and a guiding or at least visionary role regarding what future society is desirable and how we think society will evolve. (Interviewee 11)

The former chair of the town planning committee sees urban expansion in waterfront areas as critical to urban development:

We need to complement Norrköping with ... waterfront housing, and here we have discussions [on what is appropriate]. It is up to each municipality to decide, and they want to be as attractive as possible. (Interviewee 1; also Interviewees 46)

The demand for waterfront housing is identified as emanating from the public, private contractors and local politicians, often motivated by strong inter-municipal competition to increase population growth (Interviewees 1, 2, 4, 5, 9). This position involves two important questions to be balanced through planning:

On the one hand, will anything happen at all; on the other hand, will what happens actually be desirable in terms of, for example, climate change. (Interviewee 11)

The quotation illustrates a tension in planning practice, in which many interviewees agree that the first concern, facilitating urban expansion, had previously been the top priority. This orientation has been linked to "planning on demand", fostering a habit of responding positively to requests:

We often make plans on demand and test the possibilities of building in a certain location. Sometimes we are too nice and say "yes that should be possible". (Interviewee 8)

This suggests a defensive and reactive role for planning, accepting rather than proactively shaping future urban expansion in a way that merges external demand with the integration of various policy concerns. In this regard, Norrköping, like many other Swedish cities, has a history of locating settlements in sensitive areas, as described by a politician with forty years of experience in urban planning:

We have already built in sensitive areas. ... We knew about the problems but exploited [the areas] for economic gain, which we still do, and this is a problem. (Interviewee 8)

Several historical examples of problematic situations are described in which risks identified during planning or construction led to only minor adjustments rather than a precautionary approach of retreat or reflecting on the consequences of continuous expansion. A notable example concerns an excavator sinking at the construction site, "solved" by removing the two sites nearest the shoreline in an attempt to "fix" the problem but otherwise going ahead. Despite this historic legacy, planners see contemporary planning as standing at a crossroads in terms of how to approach waterfront spatial planning, as exemplified by the following: 
We haven't really taken a stand yet. When I started it was more "exploitation at any cost", since it is seductive to develop these [waterfront] areas, but now we hear more precautionary statements. (Interviewee 5; also Interviewees 4, 6).

The interviews with politicians further establish the divergence between different positions regarding climate adaptation in waterfront spatial planning, supporting previous evidence that spatial planning in practice is often based on contradictory narratives and aspirations (Clifford, 2012; Inch, 2012). The new chair of the planning committee claims that Norrköping recognizes the necessity of balancing climate risks, shoreline protection rules and waterfront planning ambitions guided by a clear political position on climate change as non-negotiable:

The laws of nature are non-negotiable. We have built our society on the illusion that they are and we keep pushing the boundaries all the time. (Interviewee 3)

Several politicians also emphasized the need to withstand pressures for inappropriate waterfront planning, in what is clearly identified as a more proactive political role:

I wish that the committee had a long-term [view of] responsibility and ensured that there was a long-term idea and was really able to withstand pressure when we know that building won't be sustainable in the long run. (Interviewee 11; also Interviewee 10)

This is particularly important, because once a local development plan is approved, politicians have taken responsibility for the appropriateness of the location, according to the Swedish Planning and Building Act.

Some interviewees see spatial planning as also having a political role to facilitate better matching of demand and supply, i.e. "to make people demand what is long-term sustainable", and to make society realize that attractive housing must be robust and safe (Interviewees 5, 10, 11). Appropriate inner-city areas could clearly be used for new residential construction exist, but these are seen as too unattractive by developers, who claim that people do not want to live in them. To change this perception, more aggressive marketing of appropriate areas is suggested, which would give the politics of spatial planning an important role (Interviewees $7,8)$. These statements suggest an intention not only to defensively meet demand but also to switch roles and create demand to influence what is desired, in line with theoretical definitions of strategic and proactive spatial planning (Albrechts, 2010; Healey, 2009; Tewdwr-Jones et al., 2010). Other interviewees, however, are less enthusiastic about such a role:

We are not elected to tell people where to live and not [to live]. Then they will vote for someone else next time. ... but we do need to be clear about what areas are inappropriate or what technical measures can be used to avoid problems. (Interviewee 9)

From this perspective, the role of politicians in spatial planning is instead to have a say in how problems could best be avoided. However, other sides of waterfront planning were also expressed in our interviews. Instead of stressing that the laws of nature are non-negotiable, 
some interviewees claimed that waterfront spatial planning can, in practice, instead be seen as based on negotiating political priorities and interpretations of climate change impacts and vulnerabilities. In the words of the new chair of the town planning committee:

Then there is always the question of how much money we can invest to address risks, what the probabilities are of flooding and what damage we are prepared to accept. ... We won't be able to find $100 \%$ protection. (Interviewee 3 )

In the hope of bringing clarity to the practical management of climate risks, city planning office officials have recently outlined a general approach in a new risk appendix to spatial planning. The appendix, based on a combination of scientific and national policy recommendations, assesses water levels and flow probabilities with return periods of 100 and 1000 years and the probable 10,000-year maximum flow (Norrköping, 2012). The return period concerns the probability of flood occurrence, an average value expressing the frequency at which a flood of a certain size is expected (SOU, 2007, p. 60). Local inventories indicate that approximately 2800 buildings in Norrköping are at risk in the various return periods (Norrköping, 2012, p. 39). The risk appendix further states that the combined effect of a sea level rise of one metre, an extreme water level in the river and a 100-year flood would raise the sea level in the inner Bråviken bay by an estimated 2.38 metres above the current average (according to the new flood-level system; RH, 2000). Consequently, the risk appendix recommends that new settlements should be located 2.5 metres above the current average (Norrköping, 2012). The planners hope that the appendix will give them leverage in taking necessary precautions in spatial planning practice in setting an absolute limit (Interviewees 4-6). The risk appendix also contains an exception, permitting the practical and concrete outcome of climate adaptation in waterfront spatial planning to be negotiated case by case.

Detailed Waterfront Spatial Planning in Kanaljorden and Lindö

Kanaljorden, located in rural Norrköping near the Göta Canal and national highway E4, was identified as appropriate for tourism, recreation and housing in the 1980s. Since the area nearest the canal is a cultural reserve, meaning no housing is allowed, the spatial planning programme states that the siting of housing there calls for careful investigation (Norrköping, 2007). The plan description and associated local development plan confirm previous political goals and sketch out housing, offices, shops and natural recreational areas to complement the current hostel with café, restaurant, meat shop, marina and veterinary clinic (Norrköping, 2009). The documents also clearly identified climate sensitivity from both cold air and mist, geotechnical difficulties associated with land subsistence and flood risk. An old embankment offers some flood protection, but complementary protection, such as land elevation and planned pathways, is needed for pedestrians and cyclists. Kanaljorden is also troubled by soil contamination and high noise levels from nearby highway traffic. Furthermore, the current shoreline protection zone covers half the area in question (Norrköping, 2007, 2009). Despite 
these challenges, Kanaljorden was seen by the former town planning committee and spatial planners as an area with potential, a diamond in the rough (Interviewees 4-6).

Development in Lindö is intended to diversify Norrköping's housing stock. A planning programme, politically approved in 2010, mandated investigating the conditions for the future restoration and development of the Lindö marina and for establishing attractive waterfront housing, including floating houses, services, commercial facilities and public areas. The marina is deemed to have huge development potential with its "beautiful views towards Bråviken and Kolmården and proximity to water, recreation and outdoor life" (Norrköping, 2010). The planning programme also notes problems with sea level rise as well as current and future flood risk in both the currently developed area and part of the planned area. Large areas of Lindö are lowland, meaning current and future exposure to flood risk. Contaminated land, topography, nature conservation values and shoreline protection compound the complications (Norrköping, 2010). The ongoing development planning clarifies the flood risk and suggests potential protective measures, such as expanding the current quayside, constructing pathways serving as embankments and elevating the ground (Interviewees 4-6).

The current waterfront planning practice illustrates how climate adaptation is negotiated via arguments about appropriate scenarios for expected local climate risks. It is clear from development planning that the conclusion of the new risk appendix, i.e. that any new settlements should be located at 2.5 metres above the average sea level, is not being applied. The following quotation illustrates the position of planners in development planning:

We have concluded that the risk of plus 2.5 metres [corresponding to the precautionary principle] is so vanishingly small that it is not worth the extra money. We instead work with plus 1.84 metres [corresponding to return periods of a hundred years] at the recommendation of consultants and the Swedish Meteorological and Hydrological Institute. (Interviewee 4; also Interviewee 5)

This statement supports the assertion that the levels recommended in the risk appendix are negotiable in current waterfront planning practices. Comparing these two planning examples reveals two opposing approaches to managing climate change risks. Our study suggests that the position taken has less to do with the severity of local climate risks than, as suggested by both planners and politicians, with the perceived attractiveness of the area. Accordingly, climate adaptation becomes a matter of negotiating case-by-case trade-offs between values. As one politician observed:

With Kanaljorden we had questions about the flood risks. We didn't want to adopt the plan and water was one argument we used. But in Lindö, where we want to adopt the plan, then the water issue was conjured up. (Interviewee 11; also Interviewees 8-10)

Likewise, several politicians claim that the positions taken in Kanaljorden, promoted by the former town planning committee, reflect weak political support: 
Kanaljorden is unprofitable and we wouldn't get our money back from the development. A lot of money is at stake in Lindö and we are prepared to take an initial loss when implementing measures because it is an attractive and important area for city development. Sometimes adaptation is politically correct and at other times it is disregarded. (Interviewee 4; also Interviewees 8, 10, 11)

Interviewees also note that they found it easier to withdraw from Kanaljorden, where less investment and property value was at stake:

We have invested a lot of money in Lindö and will do anything to save our previous investments. But no investment had been made yet in Kanaljorden, so we could stop the plan without anyone losing property value. (Interviewee 8)

The current town planning committee generally views Kanaljorden as a holdover from the previous committee. Despite the arguments favouring development in Lindö, politicians acknowledge that the climate-related risks are far from unproblematic. Some politicians fear that path dependency will create problems, i.e. that current commitments and strong beliefs in the area's attractiveness will make it difficult to change course in the future if climate problems prove unmanageable (Interviewee 11), whereas others instead believe that a change of course is likely, due to both climate risks and the difficulty of providing public transportation (Interviewees 8, 10). Furthermore, our interviewees claim that the current draft plans fail to reflect strategic planning decisions at a higher spatial level with potentially huge impacts on the Lindö area. One politician with longstanding involvement in local urban planning and construction issues clarifies how the plans for expanding the harbour in the coming 10-15 years would greatly influence the scenery of the Lindö area by establishing one of the biggest oil ports in the Baltic Sea:

We did not discuss the strategic and long-term expansion of the harbour area at all in the planning programme. This will influence the area greatly and we shouldn't allow any buildings at all in Lindö. If we scale up the map a bit, we see that this is where the big 40,000-tonne ships will enter, which is inappropriate for a housing area. (Interviewee 8)

Likewise, interviewees referred to how the new high-speed railway, Ostlänken, would influence local spatial planning in other areas of Norrköping. These examples illustrate the gap between local spatial planning and other strategic planning agendas, which also suggests temporal mismatches and a general lack of coordination in urban planning.

This analysis indicates that a fairly flexible and ad hoc approach is taken to climate adaptation in waterfront spatial planning rather than suggesting that climate adaptation would take precedence as a chief concern. Interpreting interviewee statements in light of Hurlimann and March's (2012) list of planning capacities clearly indicates that spatial planning clearly coordinates, balances and merges differing perspectives. Simultaneously, however, the guiding principles of this integration are neither consistent nor transparent to outside observers. 
Current Fragmentation: Interplay of Planning Instruments and Intra-sectoral Silos

When discussing to what extent the current orientation and manifestation of spatial planning enables proactively shaping change, according to planning theory expectations, two immediate challenges stand out in our analysis: 1) the interplay between planning instruments and 2) the current organization of planning. Regarding the former, both planners and politicians recognize that climate risks need to be managed at a general, strategic level: the municipal comprehensive plan:

It is the strongest political statement we have as to where we should develop and where we should avoid development. If things are settled at that level, we have a lot to do when it comes to contentious plans and decisions. (Interviewee 5; also Interviewees 3,6 )

The planners also criticize the current comprehensive plan in this respect:

The comprehensive plan would benefit from having a more detailed and clear direction. (Interviewee 6; also Interviewees 4, 5)

The problem with a vague comprehensive plan becomes clear when the plan is linked to local development planning, deciding what to do in concrete terms in a specific location. The risk that development planning may lose sight of general, strategic considerations is expressed by the former chair of the town planning committee:

We need to decide on principles so that we don't get stuck in one-off plans. Otherwise it is too easy to make plans for how to build without taking responsibility. You easily start thinking "What a nice place for a lovely boardwalk - you can live right next to it and we can have cafés". (Interviewee 1)

Our interviews indicate that spatial planning is currently carried out case by case. Politicians bear witness to this piecemeal approach:

We make decisions on a case-by-case basis. ... There is no strength in such planning. (Interviewee 8; also Interviewees 7, 9-11)

Current case-by-case planning risks losing sight of general considerations and of where spatial planning in a strategic sense is actually heading:

You lose sight of the big picture and it is easy to set bad priorities when you take one thing at a time. There are many things we need to consider in planning, and if you can't see the big picture then you won't know what to do. (Interviewee 11)

These interviewee statements resonate with previous studies problematizing current fragmentation in planning (e.g. Hrelja, 2011; Mickwitz et al., 2009; Newman, 2008; Vigar, 2009). Ensuring that the bigger picture of, for example, climate change is not ignored is a goal 
of the new risk appendix; however, the interviewees indicate that the problem is not necessarily solved by the appendix, since it also allows variances:

Our suggestion is a strong statement, [but] we allow variances so that we can exploit different areas. Even if there are risks of flooding, we need to be able to depart from our policy. But then we need to conduct a detailed risk analysis and assess the costs and benefits of various preventive measures. (Interviewee 6)

The planners agree that the new risk appendix supports the ongoing negotiation of as yet unsettled positions in waterfront spatial planning practice:

There will be situations in which we choose to take expensive precautionary measures in order to develop [certain areas], while in other less strategic areas for urban development we may choose a strategy of retreat. (Interviewee 6; also Interviewees 4, 5)

The exception clearly creates leverage for continued waterfront planning, as acknowledged by planners:

In theory we could end up with a situation in which the exception becomes the rule. (Interviewee 6; also Interviewees 4, 5)

Clearly, the risk appendix does not remedy the current lack of general political statements on and guidelines for climate adaptation, but instead helps maintain flexibility in planning.

Another complication when attempting to integrate divergent considerations within strategic spatial planning is the limited intra-sectoral interaction in local planning in general. Politicians argue that different tasks are kept organizationally separate today: comprehensive, strategic planning, which is the responsibility of the city council/city planning office; local development planning, which is the responsibility of the town planning committee/city planning office; and the granting of building permits, which is the responsibility of the construction and environmental protection committee/office. This organizational compartmentalization creates unfortunate intra-sectoral silos in planning practice, as described by a politician involved in urban planning and construction for 40 years:

There is a gap between the detailed thinking of the town planning committee and the strategic thinking in comprehensive planning - which is unfortunate. We also have poor communication with the construction and environmental protection committee, which deals with planning permits, meaning that some areas are developed based on kind-hearted dispensations. (Interviewee 8)

Generally, politicians call for enhanced cooperation between the political committees involved in different spatial planning activities. Lack of horizontal interaction between the town planning committee and the technical committee is also found:

We have areas we find appropriate - such as Torsviken, with a view of Bråviken and without flood risks - but which the technical committee in charge of public 
transport thinks are bad alternatives. We need better feedback and coordination.

(Interviewee 11)

Improved feedback as well as linkages with political goals is needed in order to maintain the current direction in spatial planning, since spatial planning decisions constantly influence urban development. Considerable trust is currently placed in the councillor chairing the town planning committee, who acts as mediator and communication link between the committees and the comprehensive and detailed planning functions. Furthermore, politicians perceive a disconnect between spatial planning instruments as well as a lack of political debate concerning local development planning in the town planning committee:

We need more time to discuss the plans, because all we have now are brief presentations by officials and a few papers to read but no time for them to sink in or to determine the facts. Some decisions are routine but in other situations we would need to be able to dig deeper. (Interviewee 9)

Furthermore, the same politician perceived a lack of fora in which to discuss the overall implications of the totality of individual plans, questioning the kind of society created by this grand design, the extent to which various political goals are maintained in spatial planning and the direction in which urban development is really heading. Addressing the last matter would include reflecting on the socioeconomic implications of the current approach to waterfront development, which could aggravate housing segregation (Interviewee 5). Interviewees agree that they need to apply a broader understanding of climate change to spatial planning in order to realize the potentially significant role of spatial planning in both climate adaptation and mitigation (Interviewees 1-11). Although water, in terms of sea level rise and flooding, is recognized as a major concern (Interviewees 6, 8), it is not the only climate-related issue facing spatial planning (Interviewees 3, 11). Instead of focusing on minimum floor-level requirements in waterfront areas, the concentration and densification of city centres to avoid urban sprawl is critical to creating sustainable urban quality in terms of reduced transportation demand (Interviewee 5; also Interviewees 4, 7-9, 11). The interviewees generally suggest making room for proactive strategic planning by discussing various scenarios, pathways and visions for sustainable urban planning and by considering alternative designs, directions and outcomes for urban development. Planners say that instead of being seen as reactionaries who limit spatial planning to avoiding climate risks, they should be given the opportunity to be constructive, identifying other areas and approaches to developing the city more sustainably (Interviewees 5, 6). From the interviews, we can characterize planners and politicians as in some instances embracing proactive and reflexive ideals of strategic spatial planning as outlined by planning theorists (e.g. Albrechts, 2010; Healey, 2009), but at the same time their accounts and descriptions of the practical negotiations surrounding concrete spatial planning projects and decisions are rather far afield from signalling grand transformations.

\section{Conclusions}


Given our aim of illustrating how the ideals and goals of climate adaptation are manifested in waterfront spatial planning practices, we conclude that there is a current divergence in the aims, approaches and positions of waterfront spatial planning among planners and politicians. On the one hand, we find statements favouring a precautionary approach and asserting that the laws of nature are non-negotiable. This is exemplified by the general statements and positions taken in the new risk appendix, where suggested absolute limits for waterfront planning are intended to supply guidance and positive leverage for necessary precautions, much in line with current policy expectations. On the other hand, the same appendix allows variance from the guidelines. When examining ongoing waterfront development planning, we find that the guidelines in the appendix are not being applied and that negotiated adaptation instead takes place, based on the perceived political and economic attractiveness of particular areas and on assessment of the probability of climate risks. The outline of the risk appendix thus supports continued negotiation of as yet unsettled positions in waterfront spatial planning practice. Our study suggests that the positions taken in practice have less to do with the severity of climate risks than with the perceived political and economic attractiveness of areas proposed for development. As suggested by the title of this paper, climate adaptation is sometimes politically correct and at other times disregarded. When an area's perceived attractiveness is low, climate risk serves as a pretext for not developing it and strict guidelines for precautionary action can be applied, whereas areas of high perceived attractiveness lead to climate adaptation being disregarded in favour of negotiated pragmatism allowing continued waterfront exploitation. Accordingly, climate adaptation becomes a matter of case-by-case negotiations where climate risks, instead of appearing as an unquestionable absolute, is one of many concerns dealt with in the inherently political practice of spatial planning. In our interviews, this flexible position is also linked to the concept of "planning on demand", fostering a habit of responding positively to requests but giving planning a defensive and reactive role, acceding to demand rather than proactively shaping future urban expansion. We found that the proactive and reflexive potential of spatial planning highlighted by planning theorists is impeded, despite its being an ideal invoked by both planners and politicians. In our interviews with politicians serving on the town planning committee, we found signs of a willingness to switch roles and see politics in spatial planning as a force creating more sustainable demand, shaping what is desired more strategically and proactively, although the practical realities of spatial planning as described did not match this.

We also found a fragmentation of spatial planning in terms of its instruments and organization, counteracting the proactive shaping of change in terms of climate adaptation. Given the interplay of planning instruments, it is clear that municipal comprehensive plans, as the strongest strategic political statements, are too vague to have a real impact on local development planning deciding what to do in concrete terms and specific locations. In particular, politicians in the town planning committee see a risk that ad hoc and case-by-case development planning may lose sight of general considerations, paving the way for potentially unfortunate priorities. Compared with the case-by-case planning approach identified by Nilsson from which strategic comprehensive planning was missing (Nilsson, 2007, p. 441), the problems identified here concern flexible strategic-level formulations that allow for flexibility in local development planning as well. Although coordinating, balancing 
and mediating interests are natural parts of spatial planning, the described fragmentation results in a lack of consistency, transparency and predictability in spatial planning and decision-making practices, turning development planning into a black box. This illustrates how the integrative and proactive potential of spatial planning is limited by the structure and practice of local spatial planning.

The current organization of spatial planning reflects limited intra-sectoral interaction and poor communication between actors involved in local planning at large. There is also a lack of horizontal interaction, for example, between the town planning and the technical committees, and a lack of fora in which to discuss the implications of the totality of individual plans, raising questions as to the kind of society created by this grand design, the extent to which various political goals are maintained in spatial planning, and the direction in which urban development is really heading. Maintaining the compartmentalization of both organizational and spatial planning issues entails the risk, as suggested by Nilsson (2007), that "contradictory issues never stand in direct opposition to each other, and in this way the need to make a decision with respect to the bigger picture is avoided" (p. 443). In addition, we suggest that this compartmentalization militates against the potential benefits of openly assessing various spatial planning claims and concerns in a way that could allow better policy coordination.

To conclude it is fair to say that in the case study we are witnessing spatial planning at a crossroads: it must negotiate, merge and balance societal demands while outlining a practical role for climate adaptation. There is a split between policy expectations and the practical realities of planning. On the one hand, the ideals and ambitions in current climate adaptation policy suggests that spatial planning has the potential to actively deal with climate risks and ensure adequate and necessary precautions in a sense that puts climate risks at the forefront of considerations and almost suggest planning being apolitical in nature. On the other hand, concrete manifestations of waterfront spatial planning practice illustrates planning as inherently political and in constant occupation with negotiating, merging and balancing various societal demands and in this process trying to outline a practical and flexible role for climate adaptation. The current fragmentations witnessed in planning practice means that the integrative, proactive and reflexive potentials in spatial planning to ensure and deliver climate adaptation have yet to be realized.

\section{Acknowledgements}

The authors would like to express their gratitude to the interviewees for generously sharing their views, perspectives and experiences of climate adaptation and spatial planning practices. The research was generously funded by the Centre for Municipality Studies (CKS) and has been published as part of the research project Risk, vulnerability and adaptation to climate variations and change in Östergötland. 


\section{References}

Albrechts, L. (2010) More of the same is not enough! How could strategic spatial planning be instrumental in dealing with the challenges ahead, Environment and Planning B: Planning and Design, 37(6), pp. 1115-1127.

Biesbroek, G. R., Swart, R. J. \& van der Knaap, W. G. M. (2009) The mitigation-adaptation dichotomy and the role of spatial planning, Habitat International, 33(3), pp. 230-237.

Blanco, H. \& Alberti, M. (2009) Hot, congested, crowded and diverse: Emerging research agendas in planning, Progress in Planning, 71(4), pp. 153-205.

Boverket (2009) Bygg för morgondagens klimat: Anpassning av planering och byggande [Build for the climate of tomorrow: adapting planning and building] (Karlskrona: Boverket). In Swedish.

Boverket (2010) Klimatanpassning i planering och byggande - analys, åtgärder och exempel [Climate adaptation in planning and building - analysis, measures and examples] (Karlskrona: Boverket). In Swedish.

Bramley, G. \& Kirk, K. (2005) Does planning make a difference to urban form? Recent evidence from Central Scotland, Environment and Planning A, 37(2), pp. 355-378.

Bulkeley, H. (2006) A changing climate for spatial planning, in: Campbell, H. (Ed) Is the issue of climate change too big for spatial planning?, Planning Theory \& Practice, 7(2), pp. 203-214.

Bulkeley, H. \& Betsill, M. M. (2005) Rethinking sustainable cities: Multilevel governance and the "urban" politics of climate change, Environmental Politics, 14(1), pp. 42-63.

Campbell, H. (2006) Is the issue of climate change too big for spatial planning?, Planning Theory \& Practice, 7(2), pp. 201-230.

Clifford, B. P. (2012) Reform the frontline: Reflections on implementing spatial planning in England, 2004-2008, Planning Practice \& Research. doi:10.1080/02697459.2012.725550.

Davoudi, S., Crawford, J. \& Mehmood, A. (Eds) (2009) Planning for Climate Change: Strategies for Mitigation and Adaptation for Spatial Planners (London: Earthscan). 
EC (2000) The EU Compendium of Spatial Planning Systems and Policies, Sweden (Luxembourg, European Commission, Office for Official Publications of the EC).

Flyvbjerg B. (2007) Five misunderstandings about case-study research, in: Seale C., Gobo G., Jaber F., Silverman D. (Eds), Qualitative research practice, pp. 390-404 (London and Thousand Oaks, CA: Sage).

Forester, J. (1989) Planning in the Face of Power (Berkeley and Los Angeles: University of California Press) .

Friedmann, J. (1987) Planning in the Public Domain (New Jersey: Princeton University Press).

Glaas, E., Jonsson, A., Hjerpe, M. \& Andersson-Sköld, Y. (2010) Managing climate change vulnerabilities: Formal institutions and knowledge use as determinants of adaptive capacity at the local level in Sweden, Local Environment, 15(6), pp. 525-539.

Glaas, E. (2013) Reconstructing Noah's Ark: Integration of Climate Change Adaptation in Swedish Public Policy, Doctoral Dissertation, Linköping University, 2013.

Granberg, M. \& Elander, I. (2007) Local Governance and Climate Change, Local Environment, 12(5), pp. 537-548.

Healey, P. (2007) Urban Complexity and Spatial Strategies: Towards a relational planning for our times (London: Routledge).

Healey, P. (2009) In search of the "strategic" in spatial strategy making, Planning Theory \& Practice, 10(4), pp. 439-457.

Hilding-Rydevik, T. \& Åkerskog, A. (2011) A clear case of “doublespeak": The Swedish governmental SEA implementation discourse, Journal of Environmental Planning and Management, 54(4), pp. 495-515.

Hillier, J. \& Healey, P. (Eds) (2010) The Ashgate Research Companion to Planning Theory: Conceptual Challenges for Spatial Planning (Farnham, UK: Ashgate).

Hrelja, R. (2011) The tyranny of small decisions: Unsustainable cities and local day-to-day transport planning, Planning Theory \& Practice, 12(4), pp. 511-524. 
Hurlimann, A. C. \& March, A. P. (2012) The role of spatial planning in adapting to climate change, Wiley Interdisciplinary Reviews: Climate Change, 3(5), pp. 477-488.

Inch, A. (2012) Deconstructing spatial planning: Reinterpreting the articulation of a new ethos for English local planning, European Planning Studies, 20(6), pp. 1039-1057.

Isaksson, K. \& Storbjörk, S. (2012) Strategy making and power in environmental assessments: Lessons from the establishment of an out-of-town shopping centre in Västerås, Sweden, Environmental Impact Assessment Review, 34, pp. 65-73.

Johansson, M., Hjerpe, M., Simonsson, L. \& Storbjörk, S. (2009) Hur möter östgötakommunerna klimatfrågan? En kartläggning av risker, sårbarhet och anpassning inför klimatvariationer och klimatförändringar [Municipalities of Östergötland facing climate change. Mapping risks, vulnerabilities and adaptation to climate variations and climate change] CKS Research Report No. 2009:4, Linköping University, Centre for Municipality Studies. In Swedish.

Keskitalo, E. C. H., Juhola, S. \& Westerhoff, S. (2012) Climate change as governmentality: Technologies of government for adaptation in three European countries, Journal of Environmental Planning and Management, 55(4), pp. 435-452.

Lidskog, R. \& Uggla, Y. (2009) Lokalt klimatarbete: kommunen som lärande organisation [Local climate adaptation: the municipality as learning organization], in: Uggla, Y. \& I. Elander (Eds.), Global uppvärmning och lokal politik [Global warming and local politics], pp. 63-82 (Stockholm: Santérus Academic Press). In Swedish.

Lundqvist, L. J. \& Biel, A. (2007) Coping with climate change: Sweden's climate strategy as a case in point, in: L. J. Lundqvist \& A. Biel (Eds) From Kyoto to the Town Hall: Making International and National Climate Policy Work at the Local Level, pp. 13-26 (London: Earthscan).

Lundqvist, L. J. \& von Borgstede, C. (2008) Whose responsibility? Swedish local decision makers and the scale of climate change abatement, Urban Affairs Review 43(3), pp. 299-324.

Measham, T. G., Preston, B. L., Smith, T. F., Brooke, C., Gorddard, R., Withycombe, G. \& Morrison, G. (2011) Adapting to climate change through local municipal planning: Barriers and challenges, Mitigation and Adaptation Strategies for Global Change, 16(8), pp. 889-909. 
Mickwitz, P., Aix, F., Beck, S., Carss, D., Ferrand, N., Görg, C., et al. (2009) Climate Policy Integration, Coherence and Governance PEER Report No. 2, Helsinki: Partnership for European Environmental Research.

Newman, P. (2008) Strategic spatial planning: Collective action and moment of opportunity, European Planning Studies, 16(10), pp. 1371-1383.

Nilsson, K. (2007) Managing complex spatial planning processes, Planning Theory \& Practice, 8(4), pp. 431-447.

Norrköping (2007) Program tillhörande detaljplan för fastigheten Kanaljorden 1:1

[Planprogram for Kanaljorden 1:1] (Norrköping, Sweden: Norrköpings kommun). In Swedish.

Norrköping (2009) Planbeskrivning tillhörande detaljplan för fastigheten Kanaljorden 1:1 [Plan description for Kanaljorden 1:1] (Norrköping, Sweden: Norrköpings kommun). In Swedish.

Norrköping (2010) Program tillhörande detaljplan för fastigheten Lindö 2:1 [Plan program for Lindö 2:] (Norrköping, Sweden: Norrköpings kommun). In Swedish.

Norrköping (2012) Miljö och riskfaktorer. Tillägg till översiktsplanen för Norrköpings kommun [Environment and Risk. Appendix to the municipal comprehensive plan for Norrköping] (Norrköping, Sweden: Norrköpings kommun). In Swedish.

Næss, L. O., Bang, G., Eriksen, S. \& Vevatne, J. (2005) Institutional adaptation to climate change: Flood responses at the municipality level in Norway, Global Environmental Change, 15(2), pp. 125-138.

Olesen, K. \& Richardson, T. (2012) Strategic planning in transition: Contested rationalities and spatial logics in twenty-first century Danish planning experiments, European Planning Studies, 20(10), pp. 1689-1706.

Romero-Lankao, P. (2012) Governing carbon and climate in the cities: An overview of policy and planning challenges and options, European Planning Studies, 20(1), pp. 7-26.

Runhaar, H., Mees, H., Wardekker, A., van der Sluijs, J. \& Driessen, P. P. J. (2012) Adaptation to climate change-related risks in Dutch urban areas: Stimuli and barriers, Regional Environmental Change, 12(4), pp. 777-790. 
Rydell, B., Nilsson, C., Alfredsson, C. \& Lind, E. (2010) Klimatanpassning i Sverige - en översikt: Nationell plattform för arbete med naturolyckor [Climate adaptation in Sweden - an overview] (Karlstad, Sweden: MSB). In Swedish.

SKL (2009) Läget i landet: En enkätundersökning om klimatanpassning i den fysiska planeringen [A survey on climate adaptation in Swedish spatial planning] (Stockholm: SKL). In Swedish.

Smit, B. \& Wandel, J. (2006) Adaptation, adaptive capacity and vulnerability, Global Environmental Change, 16(3), pp. 282-292.

SOU (2007) Sverige inför klimatförändringarna - hot och möjligheter [Sweden facing climate change - threats and opportunities], SOU 2007:60 (Stockholm: Fritzells). In Swedish.

Stead, D. \& Meijers, E. (2009) Spatial planning and policy integration: Concepts, facilitators and inhibitors, Planning Theory \& Practice, 10(3), pp. 317-332.

Storbjörk, S. (2007) Governing climate adaptation in the local arena: Challenges of riskmanagement and planning in Sweden, Local Environment, 12(5), pp. 457-469.

Storbjörk, S. (2010) "It takes more to get a ship to change course". Barriers for organizational learning and local climate adaptation in Sweden, Journal of Environmental Policy and Planning, 12(3), pp. 235-254.

Storbjörk, S. (2012) Adaptation policies in Sweden 2004-2011, in: D. Huitema (Ed), Handling Adaptation Governance Choices in Sweden, Germany, the UK and the Netherlands, Report W-12/07, pp. 9-19, Amsterdam: IVM Institute for Environmental Studies, Amsterdam.

Tewdwr-Jones, M., Gallent, N. \& Morphet, J. (2010) An anatomy of spatial planning: Coming to terms with the spatial element in UK planning, European Planning Studies, 18(2), pp. 239-257.

Uggla, Y. \& Storbjörk, S. (2012) Klimatrisker på planerarnas agenda: Att hantera motstridiga krav och kunskapsosäkerhet [Climate change on the agenda of planners: managing opposing demands and uncertainties in knowledge], Dansk Sociologi, 23(1), pp. 73-95. In Swedish.

Uggla, Y. (2009). Framtiden är inte längre vad den varit: Anpassning till ett förändrat klimat [The future is no longer what it was: Adaptation to a changing climate], in: Y. Uggla \& I. 
Elander (Eds) Global uppvärmning och lokal politik [Global warming and local politics], pp. 109-128 (Stockholm: Santérus Academic Press). In Swedish.

Uittenbroek, C. J., Janssen-Jansen, L. B. \& Runhaar, H. A. C. (2012) Mainstreaming climate adaptation in urban planning: Overcoming barriers, seizing opportunities and evaluating the results in two Dutch case studies, Regional Environmental Change, 13(2), pp. 399-411.

Urwin, K. \& Jordan, A. (2008) Does public policy support or undermine climate change adaptation? Exploring policy interplay across different scales of governance, Global Environmental Change 18, pp. 180-191.

Wilby, R. L. \& Keenan, R. (2012) Adapting to flood risk under climate change, Progress in Physical Geography, 36(3), pp. 348-378.

Vigar, G. (2009) Towards an integrated spatial planning?, European Planning Studies, 17(11), pp. 1571-1590.

Wilson, E. (2006) Adapting to climate change at the local level: The spatial planning response, Local Environment, 11(6), pp. 609-625.

Wilson, E. \& Piper, J. (2010) Spatial Planning and Climate Change (London: Routledge). 
Table 1. Interviewees

\begin{tabular}{|l|l|l|}
\hline Individual interviews 2010-2012 & Focus group: planners 2012 & Focus group: politicians 2012 \\
\hline $\begin{array}{l}\text { Interviewee 1: Majority } \\
\text { councillor (Social Democrat) and } \\
\text { chair of town planning } \\
\text { committee, 2010, female }\end{array}$ & $\begin{array}{l}\text { Interviewee 4: Plan architect } \\
\text { working on detailed planning at } \\
\text { the city planning office, female }\end{array}$ & $\begin{array}{l}\text { Interviewee 7: Committee member } \\
\text { (Social Democrat), male }\end{array}$ \\
\hline $\begin{array}{l}\text { Interviewee 2: Minority } \\
\text { councillor (Conservative) and } \\
\text { 2nd vice chair of town planning } \\
\text { committee, 2010, male }\end{array}$ & $\begin{array}{l}\text { Interviewee 5: Plan architect } \\
\text { working on detailed planning at } \\
\text { the city planning office, male }\end{array}$ & $\begin{array}{l}\text { Interviewee 8: Committee member } \\
\text { (Conservative), male }\end{array}$ \\
\hline $\begin{array}{l}\text { Interviewee 3: Majority councillor } \\
\text { (Green) and new chair of town } \\
\text { planning committee, 2012, male }\end{array}$ & $\begin{array}{l}\text { Interviewee 6: Spatial planner } \\
\text { working on strategic and detailed } \\
\text { planning at the city planning } \\
\text { office, special responsibility for } \\
\text { water, male }\end{array}$ & $\begin{array}{l}\text { Interviewee 9: Committee member } \\
\text { (Conservative), female }\end{array}$ \\
\hline & $\begin{array}{l}\text { Committee } \\
\text { member (Centre), male }\end{array}$ \\
\hline
\end{tabular}

